\title{
MANAJEMEN PERPUSTAKAAN SEBAGAI PENUNJANG HASIL BELAJAR SISWA DI MA NURUL HUDA PRINGSEWU KABUPATEN PRINGSEWU
}

\author{
Waqingah Husniyah, Moh Masrur, Salamun \\ Jl. Raya Wonokriyo Gading Rejo Pringsewu \\ Email: stitpringsewu@gmail.com
}

\begin{abstract}
Libraries as educational institutions and information provider institutions will have a good performance if supported by adequate management, so that all activities of the institution will lead to efforts to achieve the goals that have been declared. Based on the description above, the researcher is interested to examine more deeply about library management as supporting student learning outcomes. There are five purposes in this research are: (1) describing the meaning of library; (2) describe library technical services; (3) describe library reader services; (4) describe the benefits of libraries for school residents; And (5) to describe the involvement of citizens in the provision of libraries in MA Nurul Huda Pringsewu. Kab. Pringsewu.

This research was conducted in MA Nurul Huda Pringsewu. Kab. Pringsewu.dengan using a qualitative approach with case study design. Data collection techniques used include: (1) participant observation; (2) indepth interviews; And (3) documentation study. Checking the validity of data conducted in this study in several ways, namely: (1) persistence observation; (2) triangulation; And (3) member checks.
\end{abstract}

\begin{abstract}
Abstrak
Perpustakaan sebagai lembaga pendidikan dan lembaga penyedia informasi akan memiliki kinerja yang baik apabila didukung dengan manajemen yang memadai, sehingga seluruh aktivitas lembaga akan mengarah pada upaya pencapaian tujuan yang telah dicanangkan. Berdasarkan uraian diatas maka peneliti tertarik untuk menelaah lebih dalam tentang manajemen perpustakaan sebagai penunjang hasil belajar siswa. Ada lima tujuan dalam penelitian ini yaitu: (1) mendeskripsikan pengertian perpustakaan; (2) mendeskripsikan layanan teknis perpustakaan; (3) mendeskripsikan layanan pembaca perpustakaan; (4) mendeskripsikan manfaat perpustakaan bagi warga sekolah; dan (5) mendeskripsikan keterlibatan warga dalam penyelenggaraan perpustakaan di MA Nurul Huda Pringsewu. Kab. Pringsewu.

Penelitian ini dilakukan di MA Nurul Huda Pringsewu. Kab. Pringsewu.dengan menggunakan pendekatan kualitatif dengan rancangan studi kasus. Teknik pengumpulan data yang digunakan meliputi: (1) observasi partisipasi; (2) wawancara mendalam; dan (3) studi dokumentasi. Pengecekan keabsahan data yang dilakukan dalam penelitian ini dengan beberapa cara yaitu: (1) ketekunan pengamatan; (2) triangulasi; dan (3) pengecekan anggota.
\end{abstract}

Kata Kunci: Manajemen, Perpustakaan. 


\section{A. PENDAHULUAN}

Pembelajaran merupakan jantung dari proses pendidikan dalam suatu institusi pendidikan. Kualitas pembelajaran bersifat kompleks dan dinamis, dapat dipandang dari berbagai persepsi dan sudut pandang melintasi garis waktu. Pada tingkat mikro, pencapaian kualitas pembelajaran merupakan tanggung jawab profesional seorang guru, misalnya melalui penciptaan pengalaman belajar yang bermakna bagi siswa dan fasilitas yang didapat siswa untuk mencapai hasil belajar yang maksimal. Pada tingkat makro, melalui sistem pembelajaran yang berkualitas, lembaga pendidikan bertanggungjawab terhadap pembentukan tenaga pengajar yang berkualitas, yaitu yang dapat berkontribusi terhadap perkembangan intelektual, sikap, dan moral dari setiap individu peserta didik sebagai anggota masyarakat.

Faktor-faktor yang berpengaruh terhadap proses pembelajaran, baik secara eksternal maupun internal diidentifikasikan sebagai berikut. Faktor-faktor eksetrnal mencakup guru, materi, pola interaksi, media dan teknologi, situasi belajar dan sistem. Masih ada pendidik yang kurang menguasai materi dan dalam mengevaluasi siswa menuntut jawaban yang persis seperti yang ia jelaskan. Dengan kata lain siswa tidak diberi peluang untuk berfikir kreatif. Guru juga mempunyai keterbatasan dalam mengakses informasi baru yang memungkinkan ia mengetahui perkembangan terakhir dibidangnya (state of the art) dan kemungkinan perkembangn yang lebih jauh dari yang sudah dicapai sekarang (frontier of knowledge). Sementara itu materi pembelajaran dipandang oleh siswa terlalu teoritis, kurang memanfaatkan berbagai media secara optimal.

Berbagai usaha yang dilakukan oleh guru atau pengelola pendidik untuk lebih meningkatkan serta mendukung proses belajar agar lebih efektif dan efisien. Meskipun banyak faktor yang menentukan kualitas pendidikan atau hasil belajar. Salah satunya yang terkait dengan sumber belajar. Banyak berbagai sumber yang dapat dijadikan sebagai sumber belajar.

Oleh karenanya, belajar-mengajar sebagai suatu proses merupakan suatu sistem yang tidak terlepas dari komponen-komponen lain yang saling berinteraksi di dalamnya. Salah satu komponen dalam proses tersebut adalah sumber belajar. Sumber belajar itu tidak lain adalah daya yang bisa dimanfaatkan guna kepentingan proses belajar-mengajar, baik secara langsung maupun secara tidak langsung, sebagian atau secara keseluruhan.

Sumber belajar diartikan sebagai segala tempat atau lingkungan sekitar, benda, dan orang yang mengandung informasi dapat digunakan sebagai wahana bagi peserta didik untuk melakukan proses perubahan perilaku. Salah satu sumber belajar yang sering digunakan dalam proses belajar mengajar adalah perpustakaan dan buku. Maka dalam makalah ini akan dibahas lebih lanjut mengenai pemanfaatan perpustakaan sumber belajar.

Sebelum kita mendefinisakan perpustakaan sekolah, sebaiknya terlebih dahulu kita memahami arti atau definisi perpustakaan, sebab kata "sekolah" pada istilah "perpustakaan sekolah" merupakan kata yang menerangkan kata "perpustakaan". Memahami perpustakaan secara umum merupakaan dasar memahami perpustakaan sekolah. Perpustakaan sekolah merupakan bagian dari perpustakaan secara umum.

Perpustakaan bukan merupakan hal yang baru dikalangan masyarakat, dimana-mana telah diselenggarakan perpustakaan, seperti disekolahsekolah, baik sekolah umum maupun sekolah kejuruan, baik sekolah dasar maupun sekolah menengah.

Ada beberapa ciri perpustakaan yang dapat kita rinci sebagai berikut :

1. Perpustakaan itu merupakan suatu unit kerja Adanya perpustakaan tidak berdiri sendiri, tetapi merupakan unit kerja dari suatu badan atau lembaga tertentu. Sebagai contoh perpustakaan IKIP Malang merukana unit kerja IKIP SMP 1 Sumenep, perpustakaan SMEA merupakan unit kerja SMEA, begitu pula perpustakaan BKKBN merupakan unit kerja BKKBN.

2. Perpustakaan mengelola sejumlah bahan pustaka

Diperpustakaan disediakan sejumlah bahan pustaka, bahan pustaka bukan hanya bukubuku, tetapi juga bukan berupa buku (non book material) seperti majalah, surat kabar, brosur, mikro film, peta globe, gambargambar. Jumlah bahan pustaka ini tergantung kepada kebutuhannya yang didasarkan pada jumlah pemakainya. Semakin besar jumlah pemakainya, maka bahan pustaka yang tersedia harus semakin banyak. Bahan-bahan pustaka tersebut tidak hanya disusun dan disimpan, tetapi dikelola dengan sebaikbaiknya menurut aturan tertentu, seperti diinventarisasi, diklasifikasi menurut sistem klasifikasi tertentu, dibuatkan kartu katalog, dilengkapi dengan lidah buku, label buku, katalog buku, kartu buku sehingga siap dipinjamkan kepada siapa saja yang ingin meminjamnya, khususnya anggota perpustakaan.

3. Perpustakaan harus digunakan oleh pemakai Tujuan pengelolaan atau pengaturan bahanbahan pustaka tidak lain adalah agar dapat 
digunakan dengan sebaik-baiknya oleh pemakainya. Lebih jauh lagi adalah bagaimana agar dengan pengaturan tersebut dapat membangkitkan minat setiap pemakai untuk selalu mengunjungi perpustakaan. Dengan demikian perpustakaan tersebut akan selalu digunakan oleh pemakai atau oleh anggotanya. Pemakai perpustakaan tersebut tergantung atau sesuai dengan unit kerjanya.

4. Perpustakaan tidak hanya sebagai tumpukan buku tanpa ada gunanya, tetapi secara prinsip, perpustakaan harus dapat dijadikanatau berfungsi sebagai sumber informasi bagi setiap yang membutuhkannya.

Salah satu sarana penunjang pendidikan di sekolah adalah ketersediaan perpustakaan sekolah. Seperti tercantum dalam Undang-Undang Pendidikan Nasional Nomor 2 tahun 1989 pasal 35 , perpustakaan yang baik dan memadai serta dikelola dengan tepat akan dapat menunjang pelaksanaan kurikulum dan proses belajar mengajar sehingga dapat mempertinggi hasil pendidikan.

Slameto, yang membahas tentang belajar dan faktor-faktor yang mempengaruhinya, dimana dikatakannya"prestasi siswa dalam belajar tidak semata mata ditentukan oleh tingkat kemampuan intelektualnya akan tetapi juga ditentukan oleh faktor-faktor lain seperti motivasi, sikap, kesehatan fisik dan mental, kepribadian, ketekunan, ketersediaan sarana prasarana dan lain lain.

MA Nurul Huda Pringsewu memiliki perpustakaaan yang berdiri pada tahun 2010, atas inisiatif para alumni-alumni yang sudah melanjutkan pendidikan yang lebih tinggi. Diruangan yang berukuran kurang lebih 9 meter persegi ini terdapat buku-buku tingkat SMP, SMA, SMK dan sederajat dan kitab-kitab pondok pesantren. Dengan usia yang relatif muda ini dan dengan tenaga pengelola yang hanya memposisikan guru sebagai tenaga pustakawan tentu saja pengelolaan perpustakaan belum begitu baik.

Sarana dan prasarana perpustakaan yang berfungsi untuk membantu kerja perpustakaan sebagai sarana pendukung proses pembelajaran masih minim. Walaupun dengan sarana dan prasarana yang seadanya dan tenaga pengelola perpustakaan yang tidak memiliki dasar pendidikan khusus di bidang kepustakaan, perpustakaan MA Nurul Huda Pringsewu tetap selalu memposisikan dirinya sebagai sarana pendukung dalam kegiatan belajar mengajar di sekolah.

\section{B. TUJUAN PENELITIAN}

Adapun tujuan dari penelitian ini adalah: Untuk Mendeskripsikan Manajemen Perpustakaan Sebagai Menunjang Hasil Belajar Siswa di MA Nurul Huda Pringsewu kabupaten Pringsewu.

\section{METODE PENELITIAN}

Dalam penelitian, penulis menggunakan pendekatan kualitatif karena penelitian ini merupakan suatu bentuk penelitian yang bersifat dekriptif kualitatif. Dikatakan deskriptif kualitatif karena penelitian ini bertujuan untuk mendeskripsikan hasil pengolahan data yang berupa kata-kata, gambaran umum yang terjadi di lapangan maupun data dari dokumentasi.

Menurut M. Nazir, penelitian yang menggunakan metode deskriptif bertujuan untuk membuat deskripsi, gambaran atau lukisan secara sistematis, faktual dan akurat mengenai fakta-fakta, sifat serta hubungan antar fenomena yang diselidiki

\section{HASIL DAN PEMBAHASAN}

Berdasarkan hasil observasi di MA Nurul Pringsewu Manajemen Perpustakaan belum telaksana secara baik dan optimal, sehingga hasil belajar siswa belum berjalan dengan baik. Di dalam observasi yang dilakukan dan informasi yang diperoleh peneliti dari berbagai pihak bahwa di dalam manajemen perpustakaan atau di perpustakaan sekolah terdapat beberapa kendala atau masalah yaitu belum adanya penjaga perpustakaan, belum tersediannya buku-buku yang dapat menunjang belajar siswa, belum memiliki sarana perpustakaan yang layak.

Dalam Penelitian ini, pengumpulan data di awali dengan menghubungkan bagian administrasi MA Nurul huda Pringsewu, kemudian menemui kepala MA Nurul Huda Pringsewu untuk mendapatkan perizinan dalam penelitian, setelah mendapatkan izin, peneliti segera melaksanakan penelitian.

Barulah kemudian peneliti melaksanakan wawancara pada pihak-pihak terkait. Selaku informan, yakni proses wawancara dimulai dari kepala sekolah, guru, bagian perpustakaan dan bagian tata usaha MA Nurul Huda Pringsewu.

Setelah peneliti memperoleh data-data dari dokumentasi, wawancara, juga observasi, maka peneliti mulai merekap data-data yang telah diperoleh dan menganalisis data-data tersebut, yang disajikan dan di analisis data tersebut, peneliti dapat mengetahui bagaimana manajemen perpustakaan yang menjadi penunjang hasil belajar siswa, hasilnya dan juga faktor pendukung dan penghambat dalam 
pelaksanaanya.

\section{Manajemen Perpustakaan sebagai Penunjang Hasil Belajar Siswa}

Manajemen perpustakaan yaitu upaya mencapai tujuan secara efektif dan efesien dari suatu unit kerja atau dari suatu bahan atau lembaga tertentu yang mengelola bahan-bahan pustaka, baik berupa buku-buku naupun bukan berupa buku (non book material) yang diatu secara sistematis menurut aturan tertentu sehingga dapat digunakan sebagai sumber informasi oleh setiap pemakainya.

MA Nurul Huda Pringsewu memiliki perpustakaaan yang berdiri pada tahun 2010, atas inisiatif para alumni-alumni yang sudah melanjutkan pendidikan yang lebih tinggi. Perpustakaan ini terdapat buku-buku tingkat SMP, SMA, SMK dan sederajat dan kitab-kitab pondok pesantren. Dengan usia yang relatif muda ini dan dengan tenaga pengelola yang hanya memposisikan guru sebagai tenaga pustakawan tentu saja pengelolaan perpustakaan belum begitu baik.

Berikut hasil wawancara peneliti dengan kepala sekolah:

"Perpustakaan sebagai jantung sebuah lembaga pendidikan, sudah selayaknya mendapatkan porsi dan posisi yang strategis guna merealisasikan visi dan misi sekolah. Semua pihak, khususnya saya sebagai kepala madrasah harus memberi perhatian lebih akan eksistensi perpustakaan di sekolah, dan tidak lagi dianggap sebagai tempat menyimpan buku bekas, barang-barang tidak terpakai, bahkan tempat bermain."

Hasil Wawancara dengan Kepala Madrasah (Senin, 22 Agustus 2016, Pukul 09.00-09.30 WIB)

Dalam paparan beliau, perpustakaan sekolah perlu diperhatikan dalam pengelolaannya. Karna perpustakaan salah satu sarana yang penting dalam sebuah lembaga khususnya lembaga pendidikan di Madrasah Aliyah Nurul Huda Pringsewu.

Berkenaan dengan hal itu, berikut hasil wawancara peneliti dengan kepala madrasah: "Dari berbagai sudut pemikiran, perpustakaan SMK Nurul Huda Pringsewu berupaya melakukan terobosan dan revitalisasi peran dan fungsi perpustakaan sekolah untuk mendukung program visi dan misi sekolah. Berbagai program dan terobosan yang direncanakan, diharapkan dapat memberi ruang yang lebih besar agar perpustakaan sekolah sebagai pusat pengetahuan bagi siswa dan warga sekolah"

Hasil Wawancara dengan Kepala Madrasah (Senin, 18 Juli 2016, Pukul 09.00-09.30 WIB).
Hasil observasi di atas menunjukan bahwa penerapan manajemen perpustakaan telah dilakukan dengan cukup baik walaupun dalam beberapa poin belum diterapkan. Seperti pada rekrutmen staf dan pelatihan staf, prosedur inventaris bahan pustaka dan prosedur pengelolaan dan pembuatan bahan pustaka masih nelum diterapkan. Sehingga di dalam proses pembelajaran siswa dapat lebih mudah memahami pembelajaran dan dijadikan sebagai penunjang hasil belajar siswa khususnya siswa PAI.

\section{Hasil Penerapan Manajemen Perpustakaan di MA Nurul Huda Pringsewu}

Demikian untuk mengetahui bagaimana penerapan Manajemen Perpustakaan di MA Nurul Huda Pringsewu yaitu perpustakaan di MA Nurul Huda Pringsewu sudah ada dan dimanfaatkan untuk pembelajaran namun belum maksimal. Dalam pelaksanaan banyak yang tidak merespon dari berbagai pihak, seperti beberapa dewan guru yang enggan untuk mengajak siswanya untuk keperpustakaan ketika kegiatan belajar mengajar sedang berlangsung. Namun sebagian guru juga mampu mengajak siswanya untuk memanfaatkan perpustakaan sebagai sarana pembelajaran di sekolah.

\section{Faktor Pendukung dan Penghambat}

Suatu program yang dilaksanakan pada setiap sekolah dapat berhasil atau tidak bisa diukur dengan adanya faktor pendukung dan penghambat.

Berkaitan dengan hal tersebut di atas berikut hasil wawancara dengan kepala sekolah:

"Faktor pendukung dalam melaksanakan manajemen perpustakaan adalah adanya kerjasama antar warga sekolah dalam membangun perpustakaan sekolah, khususnya pada dewan guru masih sebagian yang mengarahkan anak didik atau siswanya untuk memanfaatkan perpustakaan sebagai sarana pembelajaran di sekolah."

"(Hasil Wawancara dengan Kepala Madrasah (Senin, 22 Agustus 2016, Pukul 08.00-09.00 WIB).

a. Faktor pendukung

Adanya kerjasama dan kekompakan antara pihak sekolah (kepala sekolah, bagian perpustakaan, guru dan komite sekolah) Pada setiap bidang pengelolaan manajemen perpustakaan. Telah dilaksanakan dengan cukup baik sesuai dengan program kerja. 
Walaupun masih ada beberapa bidang pengelolaan yang belum memadai.

\section{b. Faktor Penghambat}

Berdasarkan hasil analisis data yang disajikan, ditemukan data pada pengelolaan keuangan sekolah belum memadai yang merupakan faktor utama dalam pelaksanaan manajemen perpustakaan di MA Nurul Huda Pringsewu. Sehingga hal tersebut harus diselesaikan.

\section{E. PENUTUP \\ 1) KESIMPULAN}

Berdasarkan hasil penelitian dan pembahasan yang telah diuraikan sebelumnya, maka dapat ditarik kesimpulan bahwa manajemen perpustakaan di MA Nurul Huda Pringsewu sebagai penunjang hasil belajar siswa, faktor pendukung Manajemen perpustakaan sebagai penunjang hasil belajar siswa di MA Nurul Huda Pringsewu: pertama, Kondisi gedung yang cukup memadai dalam melakukan proses penbelajaran, serta tersedianya buku-buku yang untuk proses pembelajaran. Kedua, letak perpustakaan yang strategis. Ketiga, penataan buku yang tertata. Sementara faktor penghambat dalam penerapan manajemen perpustakaan MA Nurul Huda Pringsewu antara lain Minimnya dana serta belum terpenuhinya sarana prasarana atau perlengkapan yang dimiliki sekolah untuk perpustakaan.

Faktor pendukung yaitu adanya kerjasama dan kekompakan antara pihak sekolah (kepala sekolah, bagian perpustakaan, guru dan komite sekolah) Pada setiap bidang pengelolaan manajemen perpustakaan. Telah dilaksanakan dengan cukup baik sesuai dengan program kerja. Walaupun masih ada beberapa bidang pengelolaan yang belum memadai. Faktor Penghambat yaitu pengelolaan keuangan sekolah belum memadai yang merupakan faktor utama dalam pelaksanaan manajemen perpustakaan di MA Nurul Huda Pringsewu. Sehingga hal tersebut harus diselesaikan.

\section{2) SARAN}

Adapun saran-saran yang dapat penulis sampaikan adalah sebagai berikut:

1. Kepala MA Nurul Huda Pringsewu dapat menggunakan hasil penelitian ini sebagai bahan untuk terus mengembangkan manajemen yang sehat sesuai dengan tujuan diterapkannya Manajemen Perpustakaan Sebagai Penunjang Hasil Belajar Siswa di MA Nurul Huda Pringsewu sehingga kehadiran sekolah ini dapat memberikan kontribusi yang positif bagi kemajuan lingkungan di sekitarnya.

2. Peranan guru dalam proses belajar mengajar sangat berpengaruh terhadap keberhasilan peserta didik sehingga diharapkan guru-guru MA Nurul Huda Pringsewu dapat lebih mengembangkan kompetensinya dalam melaksanakan pembelajaran, agar proses belajar mengajar dapat mencapai hasil yang diharapkan.

3. Agar masyarakat Pringsewu dan sekitarnya dapat lebih berperanserta aktif dalam membantu mewujudkan visi dan dan misi sekolah meningkatkan mutu pendidikan/prestasi sekolah khususnya perpustakaan sekolah.

\section{DAFTAR PUSTAKA}

Akbar,Ma'ruf. Bahan Kuliyah Metodologi Penelitian, Jakarta : Program Pascasarjana Universitas Negeri Jakarta. 2008.

Al-Wasilah, Pokok-Pokok Penelitian Kualitatif, (Jakarta : Dunia Pustaka Jaya, 2006) Hal. 195

Buchari Zainudin, DR. Organisasi Sekolah dan Manajemen, Balai Aksara, Jakarta.

Dirjen Manajemen Pendidikan Dasar dan Menengah, 2005. Panduan Sekolah Potensi Menjadi Sekolah Standar Nasional (SSN). Jakarta Direktorat Pembina SMP.

Hadari Nawawi, DR; Administrasi Pendidikan, Gunung Agung, Jakarta, 1981

Hasibun, H. Melayu. 2006. Manajemen Dasar Pengertian dan Masalah. Jakarta : Bumi Aksara.

Ismed Syarif, Drs. Dan Nawas Risa, Drs; Administrasi Pendidikan Sekolah Dasar, Roda Pengetahuan, Jakarta, 1976.

Kaswan. 2011. Pelatihan dan Pengembangan untuk Meningkatkan Kerja SDM. Bandung : Alfabeta

Kortono, Kartini. 2003. Pemimpin dan Kepemimpinan, Apakah Pemimpin Abnormal Itu? Jakarta : PT Raja Grafindo Persada.

Leksy, J. Melong, metode penelitian kualitatif, Bandung : PT. Remaja Rosda Persada Perss, 2007, Cet. Ke-2.

Mulyasa, E. 2006. Menjadi Guru Profesional Bandung: PT. Remaja Rosdakarya. Mulyasa. E. 2007 Menjadi Kepala Sekolah Profesional. Bandung: PT. Remaja Rosdakarya.

Noor, Juliansyah. Metodologi Penelitian, (Jakarta : Prenadamedia Group, 2014), Cet. Ke-4, Hal. 163

Rohiat, Manajemen Sekolah (Bandung: Refika Aditama, 2012) Cet. Ke-4 Hal. 47. 
Sugiono, Metode Penelitian Kualitatif, Kuantitatif dan R\&D, (Bandung: Alfabeta, 2014), Cet. Ke-21, Hal. 32.

Suryosubroto, B. Manajemen Pendidikan di Sekolah ( Jakarta : Rineka Cipta, 2010) Hal. 202

Sutopo, H.B. 2002. Metodologi Penelitian Kualitatif, Surakarta, Universitas Sebelas Maret

Syaiful Bahri Djamarah. 2005. Guru dan Anak Didik. Jakarta: Penerbit Rineka Cipta. Wahjosumidjo. 2006. Kepemimpinan Kepala Sekolah, Tinjauan Teoritik dan Permsasalahannya, Jakarta: Penerbit PT Raja Grafindo Persada.
Tim Penyusun Kamus Pustaka, Kamus Besar bahasa Indonesia Edisi 3 (Jakarta : Balai Pustaka, 2002) Hal. 52.

Winardi. 2000. Kepemimpinan Dalam Manajemen. Jakarta: Penerbit Rineka Cipta. 